DOI: 10.33766/2524-0323.95.49-60

УДК 342.951

Федоренко М. В., аспірант Гуманітарного інституту

Таврійського наиіонального університету імені В. І. Вернадського (м. Київ, Україна)

e-mail: lermont98@gmail.com

ORCID iD : https// orcid.org/0000-0003-4392-7124

\title{
ОСОБЛИВОСТІ ЗАСТОСУВАННЯ ІСТОРИЧНО-ПРАВОВОГО ТА КОМПАРАТИВІСТСЬКОГО МЕТОДІВ ПРИ ДОСЛІДЖЕННІ СИСТЕМ УПРАВЛІННЯ ДЕРЖАВНОЮ СЛУЖБОЮ В УКРАЇНІ ТА ПОЛЬЩ
}

У статті розкрито особливості застосування історично-правового та порівняльноправового методів у складі методології дослідження проблем формування, функціонування та розвитку систем управління державною (цивільною) службою в Україні та Польші. Встановлено передумови утвердження цих методів у державно-правовій науці, починаючи 3 XIX ст.

Зауважено, що методологія державно-правових наук, яка поширювалася й на дослідження явищ адміністративного права, стала системою завдань, цілепокладань, світоглядних принципів, прийомів і способів пізнання сутності та змісту адміністративноправових явищ, режимів і статусів, а також аналізу та узагальнення відповідної правотворчої, правозастосовної, а після утвердження адміністративної юстиції в кінці XIX ст. - i правосудної діяльності.

Зроблено висновок, що історичний метод $є$ похідним від загального світоглядного принципу історизму, який використовується для дослідження більшості правових явищ, процесів, режимів і статусів, включаючи інститут державної служби. Зазначено, що аналізуючи й порівнюючи системи управління державною службою в Україні та Республіці Польща, необхідно не лише обгрунтувати висновок про їх схожість і відмінність, а й виокремити позитивні складники польської системи і сформувати пропозиції щодо можливості їх імплементації в українську систему, з урахуванням усіх чинників, які можуть нівелювати результати такої імплементації на практищі.

Ключові слова: метод, методологія, історично-правовий метод, компаративістський метод, державна служба, система управління державною службою в Украӥні та Польщі.

Постановка проблеми. Подальший розвиток України як успішної держави, а також реалізації ії проєвропейського та євроатлантичного курсу, закріпленого в преамбулі Основного Закону, залежить насамперед від формування професійного та доброчесного корпусу державних службовців в Украӥні.

Загалом вдала реформа державної служби (розмежування політичних та адміністративних посад; запровадження конкурсів на всі вакантні посади державної служби, утвердження інституту державних секретарів тощо), проведена в Україні у 2015-2020 роках, на сьогодні, у 2021 році, потребує свого логічного завершення. Зокрема, потребує удосконалення система управління державною службою в Україні, система оплати праці державних службовців, система підготовки, перепідготовки, підвищення кваліфікації та спеціалізації корпусу державних службовців, 
їх соціальний і правовий захист тощо. У контексті реформування державної служби також варто враховувати процеси децентралізації, які останнім часом доволі активно відбуваються в Україні [1; 2] та впливають на конфігурацію державної служби.

Через те для реформування державної служби в Україні та системи управління нею важливим є використання позитивного досвіду проведення подібних реформ у державах-учасницях СС із подібною правовою та управлінською системою. Такою державою, на наш погляд, може бути Республіка Польща. Своєю чергою, цілеспрямоване та комплексне дослідження систем управління державною службою в Україні та Республіці Польща, у їх порівняльно-правовому аспекті, потребує досконалої методології.

Як відомо, метод науки традищійно сприймався вченими саме як ії процедурно-евристичний компонент, як сукупність певних логічних способів і прийомів пізнання та розуміння певних явищ. Його основне призначення полягало в раціональній організації наукового дослідження, пізнавальної діяльності як такої. Саме категорії «способи» $\mathrm{i}$ «прийоми» розкривають етимологію та зміст терміна «метод»,

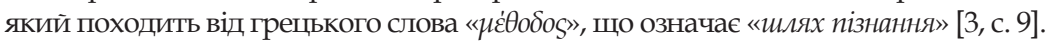

Причому, метод і методологія, як система відповідних методів, є такою ж давньою, як і сама наука та філософія, що передувала появі науці. Прийнято вважати, що основи методології пізнання політико-правових і управлінських явищ з'являються ще в античній Греції: це відома сучасникам «дедуктика Арістотеля», «герменевтика Платона» etc. Водночас, ознайомлення з пам'ятками філософської спадшини Стародавнього Сходу дозволяє віднайти основи методології й у інших державах і культурах того часу.

Так у відомому давньоіндійському епосі «Артхашастра» («Наука Політики») (IV-III ст. до. н.е.) знаходимо вчення про 32 методи, які називаються «наукою про цінності». Такими методами є: 1) визначення головних сюжетів; 2) послідовність викладення; 3) зв' язок; 4) пояснення змісту слів; 5) доказ (аргументація); 6) вказівка; 7) роз'яснення; 8) настанова; 9) цитати; 10) посилання на попереднє; 11) вказівка на наступне; 12) співставлення (аналогія); 13) очевидний висновок; 14) дилема; 15) підведення (під один розряд, категорію); 16) протиставлення; 17) доповнення; 18) погодження (з думкою інших); 19) тлумачення; 20) етимологічне пояснення слова; 21) демонстрація (ілюстрація прикладу); 22) виключення (відомих випадків); 23) спеціальні позначення чи технічні терміни (що вживаються автором); 24) спростоване положення (теза) противника; 25) заперечення на нього; 26) неспростовне положення (аксіома); 27) прийняття до уваги наступного; 28) прийняття до уваги попереднього; 29) єдина можливість; 30) необхідний вибір; 31) сукупність (можливостей); 32) невизначене рішення [4, с. 492-493]. Очевидно, білышість із наведених у «Артхашастрі» методів наукових досліджень і виклад результатів їх застосування зберігають свою актуальність донині.

Заразом методологія наукових досліджень набуває свого сучасного значення набагато пізніше, після Реформації та становлення світської філософії природного права, а також після «наукової революції» XVII ст. Мислителі XVII - XVIII ст. нама- 
гаються обгрунтувати універсальний метод для пізнання всіх явищ буття, а 3 часом - системно об'єднати вже відомі методи логіки в цілісну методологію наукових досліджень. Ужез сер. XVIII ст. у Свропі починає формуватися галузева методологія наукових досліджень у сфері природознавства, точних наук, логіки тощо.

Своєю чергою, становлення методології правових досліджень відбувається пізніше, переважно в XIX ст., під впливом згаданих здобутків у сфері розвитку методології природничих і точних наук. Як писав Х.-Г. Гадамер, «Логічне самоусвідомлення гуманітарних наук, яке супроводжувало в XIX ст. їх формування, повністю знаходилось у владі зразків природничих наук. Це демонструє вже сам розгляд терміна «гуманітарна наука» (Geisteswissenuschaft, буквально «наука про дух»)...» [5, с. 9].

У Європі того часу вже сформована методологія державно-правових досліджень, яка в цілому була універсальною як для конституційного права, так і для адміністративного (поліцейського) права. Півтора століття тому В. Сергеєвич писав щодо цього таке: «... не можна сумніватися $b$ тому, що успішна розробка будь-якої науки полягае $b$ самих тісних з 'язках з правильним розумінням ї̈ завдання і вчених прииомів. Правильне Визначення завдання науки визначає мету, до якої вона має прагнути; вірне визначення прииоомі науки є дороговказом, яким вона має йти до мети» [6, с. 1]. Таким чином, методологія, або «вчені прийоми» почали визнаватися правниками запорукою успішного досягнення мети і завдань наукових досліджень.

3 розвитком загальної методології правових досліджень відповідний поступ отримала й галузева методологія юридичних досліджень, у тому числі й методологія державно-правових досліджень, яка поширювалась на явища адміністративного права, включаючи питання державної служби, функціонування системи управління державною службою та ін.

Аналіз останніх досліджень і публікацій. Питання методології наукових досліджень, у контексті предмету цієї публікації, залишаються на сьогодні, з одного боку, традиційними для наукознавства, науки публічного права та адміністративно-правової науки зокрема, а з іншого - щодо особливостей застосування окремих методів дослідження систем управління державною службою - малодослідженими.

При підготовці цієї публікації нами використовувалися роботи таких правознавців сер. XIX-поч. XX ст.: В. Сергєєвич [6], Ю. Гачек [7], О. Градовський [8], Д. Дюгамель [9], М. Загоскін [10], В. Івановський [11], М. Лазаревський [12], Й. Ольшевський [13], О. Романович-Словатинський [14] та ін.; були враховані також попередні авторські дослідження $[16 ; 17 ; 18]$.

Формулювання цілей. Загальна мета статті полягає в розкритті сутності, змісту, призначення та особливостей застосування історично-правового та порівняльно-правового методів у складі методології дослідження проблем формування, функціонування та розвитку систем управління державною (цивільною) службою в Україні та Польщі.

Викладення основного матеріалу. Сутність, зміст та особливості застосування методів наукових досліджень у їх системному об'єднанні в методологію пізнання державно-правових явищ, режимів, процесів і статусів одним із перших в 
Україні розкрив професор Київського університету Св. Володомира О. Романович-Словатинський у своїй роботі «Посібник для вивчення російського державного права за методом історично-догматичним» (1872 р.). Так серед «прийомів buвчення позитивного права», тобто методів, які рекомендувалися ним для застосування ученими, у тому числі й для дослідження т.зв. «підлеглої влади - чиновників, які відправляли відомі посади» за Статутами про службу цивільну, професор виокремлював:

а) метод догматичний, який «установлюе своїм завданням згрупувати і коментувати діюче позитивне право, наскільки воно прикладне та обов'язково в ией час»;

б) метод філософський, діалектичний, який «порівнюе норми діючого права з загальними початками, фрілософськими, аналізуе ијі норми з точки зору постулатів теоретичного розуму»;

в) метод історичний, що «успадковує, як генетично нашаровувалися діючі норми позитивного права, установлювалися та поступово розвивалися, за ступенем історичного розвитку народу»;

г) метод порівняльний, що «роз'яснюе позитивне право якогось народу шияххом по-рівняння з позитивним правом одного з багатьох інших народів» [14, с. 7; 9].

При тому О. Романович-Словатинський виокремлював недоліки застосування вищеназваних методів поодинщі, роздільно один від одного. Так «догматичний прийом призводить до емпіризму, розвиває суху формалістику, бюрократичну рутину ...Історичний метод у своєму однобокому застосуванні зосереджує увагу на минулому, відводить очі від теперішнвого часу, розвивае надмірні симпатії до віджилих форм» [14, c. 9], - писав учений. Унаслідок цього, О. Романович-Словатинський обгрунтував висновок: «для того щоб добре вивчити і зрозуміти догму права державного, слід вивчити ї̈ поступове історичне нашарування. ... Догматичний прииоо, таким чином, має поєднуватися з історичним» [14, с. 10].

Таким чином, методологія державно-правових наук, яка поширювалася й на дослідження явищ адміністративного права, утвердилась як система завдань, цілепокладань, світоглядних принципів, прийомів і способів пізнання сутності та змісту адміністративно-правових явищ, режимів і статусів, а також аналізу та узагальнення відповідної правотворчої, правозастосовної, а після утвердження адміністративної юстищії в к. XIX ст., - й адміністративної правосудної діяльності.

Об'єктом для застосування методології державно-правових досліджень, починаючи з XIX ст., стають і питання режиму державної (цивільної) служби, зокрема й питання побудови і забезпечення ефективного функціонування системи управління державною службою, з огляду на позитивний досвід іï розвитку в інших державах. У першу чергу, мова йде про держави Західної Європи і Північної Америки, де після революцій і війн за незалежність у XIX ст. започаткували розбудову моделей публічної служби (державної, військової, самоврядної), які трансформували ії з аристократичної (привілеї за часів абсолютизму з конституційним правом на рівний доступ до публічної служби на засадах патріотизму, доброчесності та професіоналізму).

Цілком логічно, що для досягнення мети і завдань дослідження становлення та розвитку систем управління державною службою в Україні, у порівнянні з аналогічною адміністративною системою в Польщі, основними методами є, у першу 
чергу, історичний і порівняльний (компаративістський). Ці методи є досить популярними у вчених-правників, але для цілей нашого дослідження вони мають особливості свого застосування.

Як відомо, історичний є традиційним методом соціогуманітарних досліджень. Його застосування передбачає виявлення генезису та особливостей розвитку досліджуваного явища, режиму, статусу, інституту тощо. Застосування цього методу дає можливість виявити їх сутність (походження), зміст і визначити перспективи подальшого розвитку, оцінити особливості історичних транзитів досліджуваного об'єкта. Щодо застосування історичного методу для дослідження державно-правових явищ, режимів, статусів й інститутів, насамперед інституту державної служби, то в правознавстві він у чистому вигляді використовується рідко. Як уже зазначалось попередньо, історичний метод іще в XIX ст. почали поєднувати 3 догматичним.

Історично-догматичний метод отримав значне поширення серед дослідників у науці державного права, яка умовно поділялася на державне конституційне право та адміністративне (поліцейське) право (у другій п. XIX ст. - на п. XX ст.). Ціла плеяда тогочасних правознавців (українців, росіян, поляків та ін.), які працювали на території Російської імперії, видали цикл робіт, у яких було сформовано вчення про цивільну публічну службу, з урахуванням ії історичного розвитку, як правило, з часів Київської Русі.

До прикладу, другий том фундаментальної роботи О. Градовського «Початки російського державного права» мав назву «Сутність державних посад і вчення про службу цивільну». У ньому, зокрема, містились самостійні глави, присвячені розвитку посад у Західній Європі та Росії. При тому, особлива увага приділялася утворенню посад державної служби із часів Петра I [8, с. 9-46].

Такий поділ генезису та еволюціонування державної (цивільної) служби на землях, які входили до складу Російської імперії на допетровську епоху й післяпетровську епоху, став результатом застосування правознавцями історичного (історично-догматичного) методу ще з часів одного $з$ перших видань у сфері державного права - роботи Д. Дюгамеля «Досвід державного права Російської імперії» (1833 р.). У ній Д. Дюгамель наводить Указ Петра Івід 24 січня 1721 р. про чини, як цивільні, так і військові, які поділяються на 14 класів (т.зв. «Табель про ранги») i, по суті, здійснює коментар щодо застосування цього Указу на час написання ним своєї роботи [9, с. 66-81]. Причому, звернемо увагу на те, що запровадження Петром I Табеля про ранги припало на початок ліквідації Російською імперією української державності.

За відомого негативного впливу Петра I на згортання т.зв. «Козацької держави» в Україні [19], Петровський Табель про ранги відіграв загалом позитивну роль у розвитку публічної служби в Російській імперії, до складу якої було включено й більшу частину Українських земель. У цьому сенсі важливою науковою розвідкою, заснованою на історично-догматичному методі, стало дисертаційне дослідження М. Загоскіна «Нариси організації та походження служилого стану в доПетровській Русі» (1876р.), у якій учений грунтовно досліджує виникнення основ 
державних відносин службових відносин загалом та зокрема в Давній Русі, і в т.зв. «удільно-вічевий» період [10, с. 3-59].

Застосування історичного методу, у його різноманітних інтерпретаціях, знаходимо і в роботах учених у галузі державного та поліцейського права. Зокрема, досліджуваний нами метод у своєму підручнику згадував В. Івановський, який відносив до основних методів такі: індуктивний метод, історико-порівняльний або соиіологічний i, власне, юридичний метод [11, с. 14].

Зауважимо, що наведене положення підручника В. Івановського засвідчує поступову втрату популярності історико-догматичного методу досліджень на користь історично-правового та історично-порівняльного, коли дослідники аналізують становлення та розвиток державної служби, порівнюючи ці процеси з аналогічними в конституційних державах Західної Європи і США. Прикладом вдалого застосування цього методу вважаємо появу другого тому з адміністративного права «Лекцій з державного права» (1910) проф. М. Лазаревського. У цій роботі, подібно з вищеохарактеризованою працею О. Градовського, учений робить історично-порівняльний екскурс у становлення державної служби в Росії та Німеччині, Франщії, Англії та Північній Америщі [12, с. 52-77].

ще одним прикладом позитивного застосування історичного методу є робота польського дослідника Й. Ольшевського «Бюрократія», написана в 1903 р. у Львові (Лемберзі). У ній дослідник вмістив фундаментальний розділ, присвячений «історії бюрократизму», у якому дослідив утвердження та розвиток інституту державних чиновників із часів східних деспотій і розвитку бюрократії на межі XIX i XX ст. Причому, учений зазначає про дихотомічний зв'язок характеру посад із особливостями конкретних історичних епох. «Тєю мірою, як з перебігом історії ююдства змінювалися джерела, із яких витікало керівництво суспільними справами, змінювався й характер посад» [13, с. 19], - писав Й. Ольшевський.

Для дослідження державної служби і системи управління нею, як на наш погляд, вдало застосовано історико-порівняльний та історично-правовий методи в роботі Ю. Гачека «Загальне державне право на основі порівняльного правознавства» (1913 р.). Польський правознавець, порівнюючи модель державної служби в Російській імперії з моделями публічної служби на Заході, писав наступне.

«Абсолютна монархія в Англї, Франції та Німеччині, а рівно й теперішня Росія, демонструють абсолютно своєрідне розуміння державних службових відносин. Відповідно до цъього розуміння, службовець, по суті, є лише слугою монарха, який має представляти виключно його інтереси і який за цее винагороджується монархом грошима; у будь-якому випадку він може бути відсторонений від своєї посади. Цьому положенню иуілком відповідає й тодішня юридична конструкція державно-службових відносин, яка розумілася то як приватно-правові прекарні відносини (ргесатіит) ..., то як найм послуг, ..., то як доручення, то врешті як реальний контракт» [7, с. 176].

Однак, уже в середині XIX ст. наведена модель державної служби в монархіях зазнає суттєвих трансформацій серед держав Західної Європи і США. Сутність цих змін Ю. Гачек визначає цитатою Пертеса, який у своїй роботі «Державна служба в Пруссії, 1838 р.» писав: «Сутність державної служби, у тій формі, як вона була утворена в Пруссії і правом і життям, полягае в особливому обов'язку, в роботі для держави у дусі короля» [7, с. 176]. 
Застосування ж історично-правового методу дозволило Ю. Гачеку зробити висновок, що уже на п. XX ст. «державно-службові відносини є не приватно-правові, а публічно-правові суб'єктивні відносини, особливе посилення загального ставлення суб'єкта до держави, у силу чого йому підпорядковані інші громадяни держави» [7, с. 177].

Водночас, Ю. Гачек далекий від формування догми про однозначну державницьку природу публічної служби. Він вказує на подвійну юридичну природу статусу державного службовця та пише, що ці службовці не є невідчужуваними ланками державного організму й не отримують довічної ренти, «... їх винагорода $\epsilon$ Винагородою приватно-правового найму послуг» [7, с. 177].

Підсумовуючи, зауважимо, що історичний метод є похідним від загального світоглядного принципу історизму, який використовується для дослідження більшості правових явищ, процесів, режимів і статусів, включаючи інститут державної служби. Із самого початку історичний метод поєднувався з догматичним методом та утворював вдало описаний О. Романовичем-Словатинським історично (історико)-догматичний метод. Він зумовлював дослідження явищ державного володарювання та управління, а також державної служби на основі попереднього історичного досвіду державотворення та правотворення, який не лише передував, а й передбачав сучасний для дослідника стан теорії та практики, як єдино правиль-

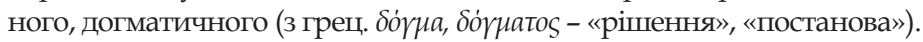

І з лібералізацію наукових досліджень у галузі державного права та державної служби історично-догматичний метод поступається місцем історично-порівняльному методу та історично-правовому, нерідко у їх поєднанні. Перший із них грунтується на порівнянні магістральних шляхів генезису та еволюціонування адміністративних режимів, зокрема, режиму державної (цивільної) служби в конституційних державах. Другий, історично-правовий, є відмовою від безапеляційних догматичних тверджень, які зводяться до коментарів позитивного законодавства, на користь виявлення парадигм правової природи державної служби, пошуку шляхів розв'язання цих парадигм на рівні доктрини, правотворчої та адміністративно-правової практики. Ці методи, на наше переконання, зберігають свою актуальність донині.

Водночас, перспективність застосування історико-порівняльного методу, який використовують як для виявлення та порівняння основних етапів генезису й еволюціонування досліджуваного явища адміністративного права в їх співвідношенні, так і для зіставлення та аналізу особливостей розвитку досліджуваного явища, режиму, статусу та інституту в різних державах чи регіонах на конкретному етапі історичного розвитку, не заперечує важливість порівняльного або компаративістського (з лат. comparativus - «порівняльний») методу, який активно застосовувався науковцями, починаючи з другої половини XIX ст. Хоча український правник Л. Ребет вбачав витоки цього методу в Античний період, добу Гуманізму та епоху Природного права [20, с. 29-30].

У правових дослідженнях не можна обійтися без формально-юридичного методу, під яким в українській науці розуміють «науковий метод, що дає змогу пізнати та дослідити [певне явище], його структурні елементи лише з юридичної точки зору, уникаючи до того ж його зв'язків із політичними, економічними та 
іншими соціальними явищами» [15, с. 40]. Водночас, порівняльно-правовий метод у правовій науці, у тому числі й у науці адміністративного права, відрізняється від емпіричного співставлення явищ управлінського характеру, насамперед чітким i послідовним алгоритмом свого застосування. Мова йде про наступну послідовність дій дослідника: а) роздільне дослідження об'єктів порівняння та виокремлення їх істотних ознак (статус, функції, структура etc); б) співставлення досліджуваних об'єктів і порівняння їхніх істотних ознак; в) виокремлення схожих і відмінних істотних ознак досліджуваного об'єкта; г) узагальнення та систематизація істотних ознак досліджуваного об'єкта; г) обгрунтування загального висновку про схожість чи відмінність досліджуваних об'єктів у контексті мети і завдань дослідження; д) формування пропозицій і рекомендацій щодо врахування результатів порівняльного дослідження в адміністративній правотворчій, правозастосовній i юрисдикційній діяльності.

Таким чином, аналізуючи і порівнюючи системи управління державною службою в Україні та Республіці Польща, необхідно не лише обгрунтувати висновок про їх схожість і відмінність, а й виокремити позитивні складники польської системи і сформувати пропозиції щодо можливості їх імплементації в українську адміністративно-правову систему, з урахуванням усіх чинників, які можуть нівелювати результати такої імплементації на практиці.

Висновки. Підсумовуючи, зауважимо, що історично-правовий і порівняльний (компаративіський) методи є ключовими в комплексному дослідженні систем управління державною (цивільною) службою в Україні та Польщі. Їх застосування дозволяе виявити витоки й еволюціонування інституту державної (цивільної) служби за часів формування та відродження національної державності, а також у часи перебування наших держав у склад Російської та Австро-Угорської імперій, у складі колишньього СРСР та в складі т.зв. «соціалістичного табору» й за часів проголошення та відновлення державного суверенітету. Тож слід зіставити, проаналізувати і порівняти системи управління державною (публічною) службою в Україні та Польщі, виокремити переваги і недоліки порівнюваних систем, оцінити перспективи рецепції вдалих складників польської моделі управління цивільної служби в систему управління державною службою в Україні тощо.

Очевидно, історично-правовий і порівняльний (компаративіський) метод не вичерпують весь арсенал методології дослідження систем управління державною (цивільною) службою в наших країнах. Зрозуміло, що функціонування досліджуваних адміністративно-правових систем, їх внутрішня побудова та статус складових елементів (суб'єктів, інституцій) потребують застосування системно-функціонального методу, методу правового моделювання та інших.

\section{Використані джерела:}

1. Данилишин Б. М. Пилипів В. В. Децентралізація у країнах СС: уроки для України. Регіональна економіка. 2016. № 1. С. 5-11.

2. Нестерович В. Ф. Децентралізація як конституційний принцип здійснення публічної влади на регіональному та місцевому рівнях. Науковий вісник Дніпропетровського державного університету внутріниніх справ. 2019. № 3. С. 47-54. 
3. Федоренко В. Л. Методологія сучасних конституційно-правових досліджень в Україні : наук. доповідь. НАПрН України, Київський регіональний центр. Київ: Ліра, 2015. 64 c.

4. Артхашастра,Ж или Наука Политики. Пер. с санскрита. Издан. подгот. В. И. Кальянов. Москва : Научно-издат. центр «Ладомир»; Изд-во «Наука», 1993. 793 с.

5. Гадамер Х.-Г. Истина и метод: Основы философской герменевтики. Пер. с нем. Общ. ред. и вступ. ст. Б. Н. Бессонова. Москва : Прогресс, 1988. 704 с.

6. Сергеевич В. Задача и метода государственных наук. Очерки современной политической литературы. Москва : Типогр. Грачова и Комп., 1871. VIII с., 231 с.

7. Гачек Ю. Общее государственное право на основе сравнительного правоведения. Часть І. Право современной монархии. Под ред. и с пред. М. А. Рейснера. Авториз. пер. с нем. М. Я. Лазерсона. Рига: Издее «Наука и Жизнь», 1913. 213 с.

8. Градовский А. Начала Русского государственного права. Том II. Органы управления. Санкт-Петербург : Типогр. М. М. Стасюлевича, 1881. VIII с., 459 с.

9. Д... [Дюгамель]. К. Опыты государственного права Российской империи. СанктПетербург : В Типограф. Импер. Российской Академии, 1833. V., 414 с.

10. Загоскин Н. Очерки организации и происхождения служилого сословия в допетровской Руси. Исследов. кандидата права. Казань : В Университ. Типограф., 1875. 216 с.

11. Ивановский В. В. Учебник административного права (Полицейское право. Право внутреннего управления). Казань : Типо-литография Императорского Ун-та, 1907. 546 c. Х., С. 14.

12. Лазаревский Н. И. Лекции по русскому государственному праву. Том II. Административное право. Ч. 1. Органы управления. Санкт-Петербург : Типогр. Санкт-Петербург. Общ. «Слово», 1910.509 с.

13. Ольшевский И. Бюрократия. Москва : Изд-во В. М. Саблина, 1906. 417 с., VIII.

14. Романович-Славатинский А. Пособие для изучения русского государственного права по методу историко-догматическому. Выпуск первый и второй. Киев : В Университ. Типографии, 1872. 286 с.

15. Нестерович В. Ф. Предмет і метод виборчого права України. Вісник Луганського державного університету внутрішніх справ імені Е. О. Дідоренка. 2018. № 3. С. 35-42.

16. Федоренко В. Л. Федоренко М. В. Системи управління державною службою в Україні та Польщі: порівняльно-правовий аспект. Вісник Луганського держ. університету Внутр. справ ім. Е.О. Дідоренка. 2020. № 3 (91). С. 205-217.;

17. Федоренко М. В. Генезис системи управління державною (публічною) службою в Україні та Республіці Польща: адміністративно-правові аспекти. Експерт: парадигми юридичних наук і державного управління. 2021. № 2(14). С. 169-190.

18. Федоренко М. В. Особливості застосування порівняльно-правового методу при дослідженні системи управління державною службою в Україні та Польщі. Сучасні аспекти модернізації науки: стан, проблеми, тенденції розвитку : матеріали ХІІІ Міжнар. науковопракт. конф., м. Київ; Бухарест, 07 вересня 2021 р. За ред. Є. О. Романенка, І. В. Жукової. Київ; Бухарест : ГО «ВАДНД», 2021. С. 71-75.

19. Шевчук В. Козацька держава як ідея в системі суспільно-політичного мислення XVI-XVIII століть / У двох книгах. Книга 1. Київ : ТОВ «Вид-во «Кліо», 2019. 792 с., іл.

20. Ребет Л. М. Порівняльна метода в науці права: наукове вид. Упоряд.: О. В. Кресіна, I. В. Кресіної. Київ-Мюнхен : Україн. вільн. ун-т, Центр порівн. правозн. Інституту держ. і права ім. В. М. Корецького НАН України. Київ : Логос, 2017. 231 с. 


\section{References:}

1. Danylyshyn, B. M., Pylypiv, V. V. (2016) Detsentralizatsiya u krayinakh YES: uroky dlya Ukrayiny. Rehional'na ekonomika - Regional economy, 1, 5-11. [in Ukrainian].

2. Nesterovych ,V. F. (2019) Detsentralizatsiya yak konstytutsiynyy pryntsyp zdiysnennya publichnoyi vlady na rehional'nomu ta mistsevomu rivnyakh. Naukovyy visnyk Dnipropetrovs'koho derzhavnoho universytetu wnutrishnikh sprav - Scientific Bulletin of Dnipropetrovsk State University of Internal Affairs, 3, 47-54. [in Ukrainian].

3. Fedorenko, V. L. (2015) Metodolohiya suchasnykh konstytutsiyno-pravovykh do slidzhen' v Ukrayini : nauk. dopovid'. NAPrN Ukrayiny, Kyivs'kyy rehional'nyy tsentr. Kyiv : Lira. [in Ukrainian].

4. Artkhashastra yly Nauka Polytyky (1993) Per. s sanskryta. Yzdan. podhot. V. Y. Kal'yanov. Moskva : Nauchno-yzdat. tsentr «Ladomyr»; Yzd-vo «Nauka». [in Russian].

5. Hadamer, KH.-H. (1988) Ystyna y metod: Osnovy fylosofskoy hermenevtyky. Per. s nem. Obshch. red. y vstup. st. B. N. Bessonova (Ed.). Moskva : Prohress. [in Russian].

6. Serheevych, V. (1871) Zadacha y metoda hosudarstvennykh nauk. Ocherky sovremennoy polytycheskoy lyteratury. Moskva : Typohr. Hrachova y Komp. [in Russian].

7.Gachek, Yu. (1913) Obshchee hosudarstvennoe pravo na osnove sravnytel'noho pra vovedenyya. Pravo sovremennoy monarkhyy. Pod red. y s pred. M. A. Reysnera. Avtoryz. per. s nem. M. YA. Lazersona (Ed.) Part I. Ryha : Yzd-e «Nauka y Zhyzn'». [in Russian].

8. Hradovskyy, A. (1881) Nachala Russkoho hosudarstvennoho prava. Vol. II. Orhany upravlenyya. Sankt-Peterburh : Typohr. M. M. Stasyulevycha. [in Russian].

9. D... [Dyuhamel']. K. (1833) Opyty hosudarstvennoho prava Rossyyskoy ymperyy. Sankt-Peterburh : V Typohraf. Ymper. Rossyyskoy Akademyy. [in Russian].

10. Zahoskyn, N. (1875) Ocherky orhanyzatsyy y proyskhozhdenyya sluzhyloho soslovyya v dopetrovskoy Rusy. Yssledov. kandydata prava. Kazan': V Unyversyt. Typohraf. [in Russian].

11. Yvanovskyy, V. V. (1907) Uchebnyk admynystratyvnoho prava (Polytseyskoe pravo. Pravo vnutrenneho upravlenyya). Kazan' : Typo-lytohrafyya Ymperatorskoho Un-ta. [in Russian].

12. Lazarevskyy, N. Y. (1910) Lektsyy po russkomu hosudarstvennomu pravu. Tom II. Admynystratyvnoe pravo. Part. 1. Orhany upravlenyya. Sankt.-Peterburh : Typohr. SPb. Obshch. «Slovo». [in Russian].

13. Ol'shevskyy, Y. (1906) Byurokratyya. Moskva : Yzd-vo V. M. Sablyna. [in Russian].

14. Romanovych-Slavatynskyy, A. (1872) Posobye dlya yzuchenyya russkoho hosudarstvennoho prava po metodu ystoryko-dohmatycheskomu. Issue 1-2. Kyiv : V Unyversyt. Typohrafyy. [in Russian].

15. Nesterovych, V. F. (2018) Predmet i metod vyborchoho prava Ukrayiny. Visnyk Luhans'koho derzhavnoho universytetu vnutrishnikh sprav imeni E. Didorenka - Bulletin of Luhansk State University of Internal Affairs named after E. Didorenko, 3, 35-42. [in Ukrainian].

16. Fedorenko, V. L. Fedorenko, M. V. (2020) Cystemy upravlinnya derzhavnoyu sluzhboyu v Ukrayini ta Pol'shchi: porivnyal'no-pravovyy aspekt. Visnyk Luhans'koho derzhavnoho universytetu vnutrishnikh sprav imeni E. Didorenka - Bulletin of Luhansk State University of Internal Affairs named after E. Didorenko, 3 (91), 205-217. [in Ukrainian].

17. Fedorenko, M. V. (2021) Henezys systemy upravlinnya derzhavnoyu (publichnoyu) sluzhboyu v Ukrayini ta Respublitsi Pol'shcha: administratyvno-pravovi aspekty. Ekspert: paradyhmy yurydychnykh nauk $i$ derzhavnoho upravlinnya - Expert: paradigms of legal sciences and public administration, 2(14), 169-190. [in Ukrainian]. 
18. Fedorenko, M. V. (2021) Osoblyvosti zastosuvannya porivnyal'no-pravovoho me todu pry doslidzhenni systemy upravlinnya derzhavnoyu sluzhboyu v Ukrayini ta Pol'shchi. Suchasni aspekty modernizatsiyi nauky: stan, problemy, tendentsiyi rozvytku: materialy XIII Mizhnar. naukovo-prakt. konf., m. Kyiv; Bukharest, 07 veresnya 2021 r. - Contemporary aspects of modernization of science: country, problems, development trends: materials of the XIII Mizhnar. scientific and practical. conf., m. Kiev; Bucharest, 07 spring 2021 r. YE. O. Romanenko, \& I. V. Zhukova (Eds.). Kyiv ; Bukharest : $\mathrm{HO}$ «VADND». [in Ukrainian].

19. Shevchuk, V. (2019) Kozats'ka derzhava yak ideya v systemi suspil'no-politychnoho myslennya XVI-XVIII stolit' (in 1-2; 1). Kyiv : TOV «Vyd-vo «Klio». [in Ukrainian].

20. Rebet, L. M. (2017) Porivnyal'na metoda v nautsi prava: naukove vyd. O. V. Kresin, \& I. V. Kresina (Eds.). Kyiv-Myunkhen : Ukrayin. vil'n. un-t, Tsentr porivn. pravozn. Instytutu derzh. i prava im. V. M. Korets'koho NAN Ukrayiny. Kyiv : Lohos. [in Ukrainian].

Стаття надіӥшиа до редколегії 10.09.2021

Федоренко М. В., аспирант Гуманитарного института

Таврического национального университета имени В. И. Вернадского (г. КиеВ, Украина)

\section{ОСОБЕННОСТИ ПРИМЕНЕНИЯ ИСТОРИКО-ПРАВОВОГО И КОМПАРАТИВИСТСКОГО МЕТОДОВ ПРИ ИССЛЕДОВАНИИ СИСТЕМ УПРАВЛЕНИЯ ГОСУДАРСТВЕННОЙ СЛУЖБОЙ В УКРАИНЕ И ПОЛЬШЕ}

В статье раскрыты особенности применения историко-правового и сравнительноправового методов в составе методологии исследования проблем формирования, функционирования и развития систем управления государственной (гражданской) службы в Украине и Польше. Установлены предпосылки утверждения этих методов в государственно-правовой науке, начиная с XIX в. Отмечено, что методология государственно-правовых наук, которая распространялась и на исследования явлений административного права, стала системой задач, целеустремлений, мировоззренческих принципов, приемов и способов познания сущности и содержания административно-правовых явлений, режимов и статусов, а также анализа и обобщения соответствующей правотворческой, правоприменительной, а после утверждения административной юстиции в конце XIX в. - и правосудной деятельности.

Ключевые слова: метод, методология, исторически-правовой метод, компаративистский метод, государственная служба, система управления государственной службой в Украине и Польше.

Fedorenko M., Graduate Student of the Humanities Institute of the

Tavriya National University named after V. I. Vernadskoho (Kyiv, Ukraine)

\section{FEATURES OF APPLICATION OF HISTORICAL-LEGAL AND COMPARATIVE METHODS IN THE STUDY OF CIVIL SERVICE MANAGEMENT SYSTEMS IN UKRAINE AND POLAND}

Features of application of historical-legal and comparative-legal methods as a part of methodology of research of problems of formation, functioning and development of systems 
of management of public (civil) service in Ukraine and Poland are revealed. The prerequisites for the approval of these methods in state and legal science since the XIX century.

It is noted that the methodology of state and legal sciences, which extended to the study of administrative law, has become a system of tasks, goals, worldviews, techniques and methods of knowing the nature and content of administrative law phenomena, regimes and statuses, as well as analysis and generalization of lawmaking, law enforcement, and after the approval of administrative justice in the end. XIX century. - and judicial activity.

It is concluded that the historical method is derived from the general worldview principle of historicism, which is used to study most legal phenomena, processes, regimes and statuses, including the institution of civil service. It is emphasized that analyzing and comparing the civil service management systems in Ukraine and the Republic of Poland, it is necessary not only to substantiate the conclusion about their similarities and differences, but also to identify positive components of the Polish system and formulate proposals for their implementation in the Ukrainian system, which may not prevent the results of such implementation in practice.

It is pointed out that the historical-legal and comparative (comparative) method does not exhaust the whole arsenal of the methodology of research of public (civil) service management systems in our countries. It is obvious that the functioning of the studied administrative and legal systems, their internal structure and the status of the constituent elements (subjects, institutions) require the use of system-functional method, the method of legal modeling and others.

Keywords: method, methodology, historical-legal method, comparative method, civil service, civil service management system in Ukraine and Poland. 